УДК: 35

https://doi.org/10.52058/2708-7530-2021-12(18)-179-187

Прав Роман Юрійович кандидат наук 3 державного управління, військовослужбовець, https://orcid.org/0000-0001-8064-2836

\title{
ЄВРОПЕЙСЬКИЙ ДОСВІД РОЗВИТКУ ДЕРЖАВНОГО УПРАВЛІННЯ У КОНТЕКСТІ НОРМАТИВНО-ПРАВОВОГО РЕГУЛЮВАННЯ СОЦІАЛЬНО-ЕКОНОМІЧНИХ ВІДНОСИН
}

Анотація. У статті висвітлюються галузеві елементи урядування, що застосовуються Європейським Союзом під час нормотворчого втілення соціально-економічної складової. Окрім того, розглядається типологія формально-методологічного впливу інститутів СС (в т.ч влади, органів законодавчої ініціативи) на вироблення політики у зазначеній сфері.

Питання становлення соціальних відносин у сфері економіки ЄС комплексне, тому його розгляд здійснено за допомогою аналізу економічної та політичної функцій окремих країн-членів та Союзу загалом. При цьому, зроблено компаративне порівняння (аналіз) між правовим регулюванням економічних відносин та економічним аспектом реалізації соціальноекономічного курсу Свропи.

У процесі дослідження розглянуто теоретико-практичні та правові аспекти реалізації соціально-економічної взаємодії у Європі. Задля цього використано ретроспективний (щодо визначення позиції держав $\mathrm{CC}$ у формуванні нормативних економічних регуляторів), системно-аналітичний (щодо тенденцій економіко-соціальних інтегративних підходів) та структурно-функціональний (щодо факторів та складових, які впливають на нормативне закріплення економічної політики в СС) методи дослідження.

У роботі проаналізовано організаційно-розпорядчі та нормотворчі аспекти, що визначають державну політику СС у соціально-економічній галузі. Також, зроблено акцент на формах та методах економіко-управлінського впливу, що застосовується державами-членами Свропейського Союзу.

Відмічено, що економічні та соціальні права за своєю природою часто знаходяться у конфронтації. Проте, у 2018 році було зроблено рух назустріч змінам - деякі країни, які отримали значну кількість «подорожуючого штату», вимагали перегляду Директиви про відрядження працівників, Переглянута Директива ставить на меті рівну оплату невиїзних (офісних) та мобільних працівників за умови, що заробітна плата регулюється відповідно до унормованих законодавчих систем.

Ключові слова: соціально-економічні відносини, нормативно-правове регулювання, управлінська політика $Є С$, економічна функція держави, владноурядові механізми. 
Prav Roman Yuriyovych Candidate of Science in Public Administration, serviceman, https://orcid.org/0000-0001-8064-2836

\section{EUROPEAN EXPERIENCE OF PUBLIC ADMINISTRATION DEVELOPMENT IN THE CONTEXT OF LEGISLATIVE REGULATION OF SOCIO-ECONOMIC RELATIONS}

Abstract. The article highlights the sectoral elements of governance used by the European Union during the rule-making implementation of the socio-economic component. In addition, the typology of formal and methodological influence of EU institutions (including the authorities, legislative initiative bodies) on policy development in this area is considered.

The issue of formation of social relations in the field of EU economy is complex, so its consideration is carried out by analyzing the economic and political functions of individual member states and the Union as a whole. At the same time, a comparative comparison (analysis) was made between the legal regulation of economic relations and the economic aspect of the implementation of the socioeconomic course of Europe.

In the course of the research the theoretical-practical and legal aspects of realization of social and economic interaction in Europe are considered. For this purpose, retrospective (on determining the position of EU states in the formation of regulatory economic regulators), system-analytical (on trends in economic and social integrative approaches) and structural-functional (on factors and components influencing the regulatory consolidation of economic policy in the EU) research.

The paper analyzes the organizational and regulatory and rule-making aspects that determine the EU policy in the socio-economic sphere. Also, emphasis is placed on the forms and methods of economic and managerial influence used by the member states of the European Union.

It is noted that economic and social rights are by nature often in confrontation. However, in 2018, there was a move towards change - some countries that received a significant amount of "traveling staff" demanded a revision of the Business Travel Directive. the fee is regulated in accordance with standardized legal systems.

Keywords: socio-economic relations, normative-legal regulation, EU administrative policy, economic function of the state, power-government mechanisms.

Постановка проблеми. Опрацювання нормативного забезпечення соціально-економічних відносин у ЄС дозволяє окреслити процес реалізації економіко-соціальної функції 3 точки зору фінансових, економічних та бюджетних функцій.

Актуально зупинитися на переплетенні, що виникає у галузі соціального співробітництва держави та бізнесу внаслідок експансії ринкових відносин. 
Економіка - соціальна надбудова будь-якої держави, тому висвітлення стандартів законодавчого нормування у СС набуває особливої доцільності.

На додаток, важливо виявити риси не лише законодавчого, але й соціально-правового влаштування економічних відносин у Свропі. Для цього логічно звернутися до Загальної декларації прав людини 1948 р. та Хартії основоположних прав Свропейського Союзу 2000 р. В даному контексті важливо виокремити та розвити ідею про індивідуальний, а не колективний характер соціально-економічних прав громадянина (резидента) ЄС.

Саме права особи та можливість їх захисту визначають рівень політикосоціальної мобільності та гуманності держави. Через це, важливо визначити ті нормативно-регулюючі інструментарії, за допомогою яких ЄС визначає концепт соціально-фінансового співробітництва.

Насамперед, важливо зробити ієрархічно-ретроспективний аналіз «соціально-ринкових моделей», що застосовують Свропарламент, Рада Європи та Європейська комісія у процесі нормотворення. Закон завжди тісно взаємодіє i3 соціальними перетвореннями : отже, важливо визначати громадянський статус в ЄС «у прив’язці» до економічної активності держави, діяльності іiі фінансових інститутів відповідно до обраної континентальної або змішаної економічної моделі.

Аналіз останніх досліджень і публікацій. Питання нормативно-правового регулювання соціально-економічних відносин у Свропі — предмет дослідження як вітчизняних, так i зарубіжних науковців. У контексті вищеокресленого дослідження застосовним є науковий доробок В. Кошелева, К. Майорової, Г. Еванса, Д. Хелда, Д. Йергіна та ін.

Мета статті - дослідити державно-управлінські аспекти у сфері нормотворчого регулювання соціально-економічних відносин серед країнчленів Свропейського Союзу.

Виклад основного матеріалу. Процес нормативно-правового забезпечення соціально-економічних відносин у СС є багатоскладним за своїм структурним архетипом.

Однак, перш ніж перейти до суто нормативного закріплення регулювання соціально-економічних відносин у $С$, варто розібрати структурнофункціональний склад спеціалізованого органу — Свропейського соціальноекономічного комітету (далі - ECEK) (European Economic and Social Committee), що є своєрідною політико-правовою надбудовою та прямо впливає на процес галузевого нормотворення у СС, координуючи даний процес. Це консультативний орган, що об’єднує організації працівників та роботодавців. Завдання - перевіряти законодавство та загальну політику ЄС щодо збалансованості та справедливості в контексті інтересів обох сторін. Орган складається iз шести секцій із окремою компетенцією : Економічний i валютний союз та економічна та соціальна згуртованість (ЕСC); Сдиний ринок, виробництво та споживання (INT); Транспорт, енергетика, інфраструктура та 
інформаційне суспільство (TEN); Зайнятість, соціальні питання та громадянство (SOC); Сільське господарство, розвиток сільських районів та навколишнє середовище (NAT); Зовнішні зв'язки (REX).

Водночас зазначимо, що Консультація ССЕК з Єврокомісією або Радою Свропи $є$ обов'язковою в деяких випадках (зокрема, щодо нормативного консалтингу); в інших — має факультативний характер. Одночасно, ЄСЕК уповноважена приймати висновки за власною ініціативою. Єдиний європейський акт (Single European Act) від 17.02.1986 р. та Маастрихтський договір від 07.02.1992 р. розширили коло питань, які є підвідомчими Комітету.

Амстердамський договір (Treaty of Amsterdam) ще більше розширив сферу взаємодії між Комітетом та Свропарламентом та дозволив останньому консультуватися з ССЕК. Зокрема, у даному Договорі включені обов'язкові елементи соціальної політики. У статті 153 Договору згадуються сфери, в яких ЄС має спеціальні регулятивні повноваження : здоров'я, безпека, умови праці, інформація та консультації працівників; отримання соціального забезпечення на роботі - для цього використовується звичайна законодавча процедура. У чотирьох інших сферах також можуть бути прийняті директиви, але лише після спеціальної процедури, в якій потрібна одностайність при голосуванні в Раді Європи, оскільки в даних сферах держави-члени зберігають право вето. Сюди відноситься соціальне забезпечення та захист працівників; захист працівників при припиненні трудового договору та економічні дивіденди за виконання робочого плану; представництво та колективний захист інтересів працівників і роботодавців, у тому числі колективне вирішення спорів (профспілки) та умови працевлаштування для громадян третіх країн, які легально проживають на території ЄC (із отриманням «соціального пакету» та економічного забезпечення) [1].

Загалом, ЄСЕК надає приблизно 170 консультативних документів i висновків на рік (близько 15\% видаються за власною ініціативою). Усі думки (позиції, роз'яснення, листи) надсилаються до органів СС, які ухвалюють рішення, а потім зазначена вище інформація публікується в Офіційному журналі СС (Official Journal of the European Union).

До інших компетентностей ЄСЕК, відповідно до офіційного веб-сайту Свропейського Союзу, варто віднести наступні : приведення політики та законодавства $Є C$ до економічних i соціальних умов, шляхом пошуку консенсусу, який служить загальному благу; сприяння розвитку ЄС, надання організаціям працівників i роботодавців та іншим групам інтересів право голосу та забезпечення соціально-владного діалогу; просування цінностей європейської інтеграції, «справи демократії участі» та організацій громадянського суспільства; налагодження соціально-економічного балансу [2].

Щодо організаційної структури ССЕК, зазначимо наступне. Члени органу представляють різноманітні організації громадянського суспільства в Свропі, включаючи бізнес, профспілки та інші. Вони висуваються національними 
урядами та призначаються Радою Європи на 5 років 3 опцією переобрання. Кількість членів у кожній країні залежить від чисельності населення цієї країни. ССЕК має президента та двох віце-президентів, що обираються на 2.5 роки та належать до групи працівників, роботодавців або іншої групи інтересів (споживачі, виробники, фермери тощо).

Крім того, ССЕК підтримує зв'язок з регіональними та національними економічними та соціальними радами по всьому $Є С$ - головним чином для обміну інформацією та обговорення окремих питань.

Наприклад, у висновку від 2009 року щодо Європейського інструменту демократії та прав людини (СІДПЛ) ЄСЕК закликав надати більшого значення економічним, соціальним i культурним правам у політиці Європейського Союзу за допомогою доступних географічних та тематичних інструментів. ССЕК також просив СС прискорити процес загальної ратифікації та імплементації Пакту ООН про економічні, соціальні та культурні права. Стаття 3 Пакту зазначає, що держави-учасниці ЄC (себто підписанти документу) зобов'язуються забезпечити рівні права на працю в соціальному та економічному вимірах. Користування економічними, соціальними та культурними правами, викладеними в Пакті ООН, також має відбуватися безперебійно.

В свою чергу, статті 6-15 Пакту ООН визнають право на працю, на користування справедливими та сприятливими умовами праці, на створення профспілок і вступ у профспілки, право на соціальне забезпечення, право на достатній рівень життя, на найвищий досяжний рівень фізичного та психічного здоров'я, на освіту та на участь у культурному житті. Ця думка також підкреслює важливість захисту кожного аспекту роботи (як вирішального елемента соціальної ідентичності кожної людини, права на громадянство та економічний добробут).

У даному висновку ССЕК вказує на зв'язок між захистом праці та всіма пов'язаними правами, встановленими основними конвенціями Міжнародної організації праці (право на працю, право на організацію та право на колективні переговори, недискримінація на роботі, заборона дитячої та примусової праці) та визнає їх основними правами людини. Ця думка була схвально сприйнята Єврокомісією, а гідність праці (за визначенням МОП) та соціальний діалог, що $\epsilon$ передумовою захисту трудових прав, знайшли належне визнання та були включені до пріоритетів ЄІДПЛ. Це стало передумовою до формування соціально-економічного наративу владно-суспільної взаємодії [3].

Щодо безпосереднього нормативно-правового регулювання соціальноекономічних відносин у Свропі, згадуємо раніше означену Хартію основоположних прав СС від 2000 р. Структурно, Хартія основоположних прав об'єднує в єдиному документі громадянські, політичні, економічні та соціальні права, раніше викладені в ряді різних міжнародних, європейських i національних джерел. Основними юридичними посиланнями на економічні та 
соціальні права, зокрема, є Загальна декларація прав людини ООН 1948 року, Європейська соціальна хартія 1961 року, Хартія Співтовариства про основні соціальні права трудящих 1989 року, заява про захист меншин на Конференції $з$ людського виміру Комісії з безпеки і співробітництва в Свропі (КБСС) у червні 1990 року, Свропейська конвенція з прав людини 1950 року, Свропейські договори, практика Суду Європейського Союзу та Конвенції Ради Європи. Хартія основоположних прав консолідує та розвиває раніше розроблений «юридичний корпус», що стосується прав людини, а отже, i економічних та соціальних прав.

Щодо постатейного соціально-економічного забезпечення відповідно до Хартії, потрібно відмітити наступні віхові елементи. Так, Розділі I про принципи поваги до людської гідності визначає іï як непорушну, статті 4 і 5 забороняють рабство, примусову працю та торгівлю людьми. Розділ II, найбільш змістовний, включає чотирнадцять статей про свободи, включаючи свободу зібрань та асоціацій. Стаття 14 запроваджує право на професійнотехнічне та безперервне навчання та на безкоштовне обов'язкове навчання. Крім того, надається свобода вибору професіі, а також право працювати та реалізовувати право заснування в будь-якій точці Свропейського Союзу. Відповідно до ст. 15 Хартії, це право також поширюється на громадян третіх країн, які мають право працювати на території держав-членів. Права супроводжуються визнанням свободи ведення бізнесу та права власності.

Рівність є принципом, що лежить в основі Розділу III Хартії, яка включає сім статей, що підтверджують повагу до культурного, релігійного та мовного розмаїття та право на рівне ставлення та можливості в усіх сферах життя та роботи. Будь-яка дискримінація також прямо заборонена за будь-якою ознакою, як-от стать, раса, колір шкіри, етнічне чи соціальне походження, генетичні особливості, мова, релігія чи переконання, політичні чи будь-які інші переконання, належність до національної меншини, майно, народження, інвалідність, вік або сексуальної орієнтації. В тому числі, зазначаються права дітей щодо праці (ст.24).

Дві статті, присвячені правам людей похилого віку та людей 3 інвалідністю, спрямовані на сприяння їх соціальній інтеграції та участі в житті громади. Розділ IV, що включає дванадцять статей, стосується солідарності, яку він визнає разом 3 роботою як основне право Союзу. Поміж тим, право працівників на інформацію та консультації на підприємстві, право на колективні переговори та дії, право на страйк, право на захист від необгрунтованого звільнення, право на умови праці, які поважають їхє здоров'я та безпеку, право на регулювати свій робочий час і відповідні періоди відпочинку та відпусток визнаються векторними на теренах країн-членів ЄС. Забороняється дитяча праця, визначається певний віковий ценз, за якого діти не можуть працювати (закінчення школи).

Наступними структурними елементами Розділу IV Хартії основоположних 
прав 2000 р. визнається можливість сім'ї отримати юридичний, економічний i соціальний захист. Також гарантується право на захист від звільнення та право на оплачувану відпустку. Крім іншого, встановлюється право на соціальну та житлову допомогу, соціальний захист і охорону здоров'я для тих, хто не має достатніх ресурсів, відповідно до правил, встановлених національним законодавством та законодавством Співтовариства (стаття 34).

Поміж тим, Хартією про основоположні права 2000 р. гарантується право на охорону здоров’я населення для забезпечення високого рівня захищеності нації (етносу) з соціально-економічної точки зору. Споживачі мають право на доступ до послуг загального економічного інтересу. Їм гарантується високий рівень захисту навколишнього середовища.

Вісім статей розділу V стосуються прав громадян. Права, які становлять економічні та соціальні права, включають свободу інформації, а також свободу пересування та проживання на території ЄC. Розділ VI, який складається 3 чотирьох статей, стосується правосуддя.

Що стосується обсягу гарантованих прав соціально-економічних прав, то стаття 52 Розділу VII передбачає, що будь-яке обмеження у здійсненні положень, визнаних Хартією, повинно передбачатися законом і поважати суть відповідних прав. Будь-які обмеження можуть бути встановлені лише в тому випадку, якщо вони необхідні та відповідають цілям, що становлять загальний інтерес, або потребі захисту прав і свобод інших осіб. Нарешті, стаття передбачає, що ніщо в Хартії не може тлумачитися як обмеження прав людини та основних свобод, визнаних конституціями держав-членів і міжнародними угодами, укладеними Союзом [4].

Відмітимо, що Лісабонський договір від 01.12. 2009 р. став передумовою значного прогресу щодо захисту основного кластеру соціально-економічних прав. Перш за все, даний нормативно-правовий акт гарантував конкретне застосування Хартії основних прав у зазначених контекстах. Таким чином, Свропейський Союз отримав низку юридично обов'язкових громадянських, політичних, а головне - економічних та соціальних прав не лише у питанні Союзу та його інституцій, а й відносно держав-членів та реалізації ними законодавства ЄС. Як наслідок подібної дискреції, Суд Свропейського Союзу отримав повноваження на стабілізацію процесу : від статичної нормативної розробки тлумачень до «компенсації» та нівелювання громадянських обмежень, що стосувалися минулої політики та партикулярних договорів [5].

Віхою в інтеграції основних соціально-економічних прав у правопорядок ЄC стало прийняття Хартії Співтовариства про основні соціальні права працівників (далі - Хартія Співтовариства) у 1989 році. Лісабонський договір визнає права, свободи та принципи, викладені в Хартії Співтовариства, і робить iii положення юридично обов'язковими (ст. 6(1) Документу). Хартія Співтовариства не тільки веде до посилення соціальних прав, але й згадує економічні права, які повинні бути узгоджені 3 соціальними правами. 
Важливим прикладом є стаття 16 Хартії Співтовариства, у якій зазначено: «Визнається свобода ведення бізнесу відповідно до законодавства Співтовариства та національних законів і практики» [6].

Потрібно зазначити, що економічні та соціальні права за своєю природою часто знаходяться у конфронтації. Проте, у 2018 році було зроблено рух назустріч змінам - деякі країни, які отримали значну кількість «подорожуючого штату», вимагали перегляду Директиви про відрядження працівників, Переглянута Директива ставить на меті рівну оплату невиїзних (офісних) та мобільних працівників за умови, що заробітна плата регулюється відповідно до унормованих законодавчих систем. 3 точки зору співвідношення згаданих прав, таким чином створюються умови менш вираженої замінності соціальних прав та цінностей економічними правами. Обставина, що ця зміна була спровокована не лише соціальними, а й економічними інтересами державчленів ЄС держав-членів, $\epsilon$ важливим пояснювальним фактором цього усунення дисбалансу між економічними та соціальними правами [7].

Розуміння та реалізація економічних та соціальних прав в $Є С$ $\epsilon$ фундаментом та «вашингтоном», що впроваджує орієнтири для відносин Союзу 3 іншими країнами. Перш за все, від країн-кандидатів на вступ до ЄС потрібна послідовність щодо захисту економічних і соціальних прав на законодавчому рівні. Захист прав також заохочується в усіх програмах політики сусідства (щодо Свро-середземноморського та / або Східного партнерства). Окрім того, поняття та концепт реалізації економічних та соціальних прав закладено в усіх угодах про асоціацію та стратегічне партнерство (наприклад, Центральна Америка та Бразилія).

Висновки. Ретельний та вибірковий аналіз аспектів структурновиконавчого та нормативно-правового регулювання соціально-економічних відносин у ЄС дає змогу визначити його галузеві риси. До них, зокрема, варто віднести ієрархічність законодавчого масиву, його різноманітність, врегулювання розбіжностей між громадянським та фінансовим аспектом державної політики Союзу. Діяльність органів накшталт Свропарламенту, Ради Свропи та Сврокомісії спрямовує та координує нормативне забезпечення у даній галузі на території країн Свропи.

\section{Jimepamypa :}

1. Held D. Global transformations / D. Held .- Oxford, 1999.

2. European Economic and Social Committee (EESC) : European Union // Режим доступу : https://european-union.europa.eu/institutions-law-budget/institutions-and-bodies/institutions-andbodies-profiles/eesc_en

3. Міжнародний пакт про економічні, соціальні і культурні права № 995042 від 19.10.1973 р. // Відомості Верховної Ради // Режим доступу : https://zakon.rada.gov.ua/ laws/show/995 042\#Text

4. Charter of Fundamental Rights (2000) : Citizens Info // Режим доступу : https://www.citizensinformation.ie/en/government_in_ireland/european_government/eu_law/charte r_of_fundamental_rights.html\# 
5. Treaty of Lisbon amending the Treaty on European Union and the Treaty establishing the European Community, signed at Lisbon, 13 Dec 2007 (in force from 01.12.2009) : official EU website // Режим доступу : https://eur-lex.europa.eu/legal-content/EN/TXT/?uri=celex\%3A12007L\%2FTXT

6. Community Charter of the Fundamental Social Rights of Workers : EuroWORK (European Observatory of Working Life) and Eurofound, 12.01. 2011 // Режим доступу : https://www.eurofound.europa.eu/observatories/eurwork/industrial-relations-dictionary/communitycharter-of-the-fundamental-social-rights-of-workers

7. Directive 96/71/EC of the European Parliament and of the Council of 16 Dec 1996 concerning the posting of workers in the framework of the provision of services : official EU website // Режим доступу : https://eur-lex.europa.eu/legal-content/EN/ALL/?uri=celex\%3A31996L0071

\section{References:}

1. Held D. Global transformations / D. Held .- Oxford, 1999.

2. European Economic and Social Committee (EESC) : European Union // Режим доступу : https://european-union.europa.eu/institutions-law-budget/institutions-and-bodies/institutions-andbodies-profiles/eesc_en

3. Міжнародний пакт про економічні, соціальні і культурні права № 995042 від 19.10.1973 р. // Відомості Верховної Ради // Режим доступу : https://zakon.rada.gov.ua/laws/ show/995 042\#Text

4. Charter of Fundamental Rights (2000) : Citizens Info // Режим доступу : https://www.citizensinformation.ie/en/government_in_ireland/european_government/eu_law/charte r_of_fundamental_rights.html\#

5. Treaty of Lisbon amending the Treaty on European Union and the Treaty establishing the European Community, signed at Lisbon, 13 Dec 2007 (in force from 01.12.2009) : official EU website // Режим доступу : https://eur-lex.europa.eu/legal-content/EN/TXT/?uri=celex\% 3A12007L\% 2FTXT

6. Community Charter of the Fundamental Social Rights of Workers : EuroWORK (European Observatory of Working Life) and Eurofound, 12.01. 2011 // Режим доступу : https://www.eurofound.europa.eu/observatories/eurwork/industrial-relations-dictionary/communitycharter-of-the-fundamental-social-rights-of-workers

7. Directive 96/71/EC of the European Parliament and of the Council of 16 Dec 1996 concerning the posting of workers in the framework of the provision of services : official EU website // Режим доступу : https://eur-lex.europa.eu/legal-content/EN/ALL/?uri=celex\%3A31996L0071 